\title{
Learning Process in Mathematics and Statistics Courses towards Engineering Students: E-learning or Traditional Method?
}

\author{
Norngainy Mohd Tawil ${ }^{1}$, Nur Arzilah Ismail ${ }^{1}$, Izamarlina Asshaari ${ }^{1}$, Haliza Osman ${ }^{1}$, Zulkifli Mohd Nopiah ${ }^{1}$ \& \\ Azami Zaharim ${ }^{1,2}$ \\ ${ }^{1}$ Unit of Fundamental Engineering Studies, Faculty of Engineering and Built Environment, Universiti \\ Kebangsaan Malaysia, Selangor, Malaysia \\ ${ }^{2}$ Centre of Engineering Education, Faculty of Engineering and Built Environment, Universiti Kebangsaan \\ Malaysia, Selangor, Malaysia \\ Correspondence: Norngainy Mohd Tawil, Unit of Fundamental Engineering Studies, Faculty of Engineering and \\ Built Environment, Universiti Kebangsaan Malaysia, 43600 UKM Bangi, Selangor, Malaysia. Tel: \\ 60-3-8921-6691. E-mail: nmtawil@gmail.com
}

Received: September 24, 2012 Accepted: November 7, 2012 Online Published: November 30, 2012

doi:10.5539/ass.v8n16p128

URL: http://dx.doi.org/10.5539/ass.v8n16p128

\begin{abstract}
Engineering courses such as Mathematics and Statistics at an undergraduate level are frequently presented to the students in traditional way. In order to be parallel with young generations in terms of technology, e-learning was introduced to engineering students in FKAB with the hope that e-learning is a way to enhance learning in a more convenience and cost-effective manner. This study examines students' perception towards the importance and usefulness of modern technologies such as e-learning (WILEY PLUS) in comparison with the more traditional lecture, as knowledge delivery or alternatively, a method of learning process. The objectives of this study are to test whether there is any difference between these two methods and to identify which method is more important and agreeable to the students. A total of 182 students of First Year and 179 of Second Year engineering students at the Faculty of Engineering and Built Environment, UKM who have taken Mathematics and Statistics courses respectively involved in this survey. The descriptive statistics such as mean and standard deviation and inferential statistics as paired t-test was used to compare these two methods. This study reveals that there is a significant difference between WILEY PLUS and lecturing in Mathematics and Statistics courses. Overall, lecturing was significantly of importance and favourable in the learning process for both courses compared to the newly-introduced WILEY PLUS.
\end{abstract}

Keywords: e-learning, WILEY PLUS, lecturing, paired t-test, students' perception, students' agreeability

\section{Introduction}

In modern technology nowadays, e-learning has been developed to become a new method of learning. Many institutions use this technology to improve the students' performance as well as lecturers. E-learning is defined as information and communication technologies; a network, including the use of the Internet and the World Wide Web; delivered on time, at any time; and an electronic exchange of information for the purpose of learning. Berge \& Collins (1995) define an E-Learning as an educational setting, in which teaching and learning take place within an internet-based environment. Along with the development of information technology, E-learning played an increasingly important role in teaching and learning (Chang and Chen, 2009). The rapid development of computer and internet technologies has led to e-learning as an important facet of education in the information age (Liaw et al., 2007). The existence of e-learning allows the students to perform various learning activities in virtual classroom. As we know, e-learning is an online learning approach and tools that can be access anytime and anywhere. Furthermore, e-learning has the potential to become a lower cost and efficient education tool (White, 2003). In Newcastle University, the e-learning has implemented in Mathematics and Statistics courses because the needs of extra functionality, more control over the content, delivery and feedback and the ability to deliver e-assessments to local schools and colleges using a variety of platforms as part of an outreach initiative to the courses (Foster et al., 2004).

Besides e-learning, traditional lecture delivery or lecturing is a common strategy method of learning process at the tertiary level. There are many definitions of lecturing persistent in the context of further education. Joan and 
Alan (1996) define that lecturing is when lecturer talks and writes something on the board, while the students listen and take copious notes of what are being written on the board (cited from Sazelli, 2009). A lecture is defined as formal lecture presented by lecturer and held between 1 to 3 hours in lecture theatre. Because of the limited time during lecture, it makes less opportunity to interact between lecturer and students in terms of asking the questions. Usually lecturer use handouts, overhead slides and audio-visual as tools for teaching (Anonymous, 2009).

There are many ways of learning process and it is depends on the lecturer to use which methods is suitable and beneficial to them. Many studies have been done on comparing the method of learning in any courses, but the results cannot tell us which method is appropriate or effective in a way of teaching process. A study by Sazelli (2009) revealed that cooperative learning as a method of active learning gives better achievement than the lecture method for almost all of the students and it is especially beneficial for those students, who were not interested towards mathematics. Another study shows there are significant differences in learning outcome between electronic learning(EL) and face-to-face $(\mathrm{F} 2 \mathrm{~F})$ learning, where students did better in EL compared to F2F (Richard, 2004).

In contrast to the previous study, lecturing is found to be better than e-learning for trainees in dentistry (Browne et.al., 2004). Johnson et al.( 2009) concluded that, majority of students who took an introductory algebra-based statistical methods at Washington State University favour the lecture-based approach to instruction regardless of gender, class and student type compare to Internet approach. Sahin and Yorek (2009) revealed that Problem Based Learning (PBL) in physics has no different than traditional instruction in influencing students' achievement. Abdullah et al. (2011) in his study of comparing effectiveness e-learning training and traditional training in industrial safety and health also found that there is no difference in the rating of the effectiveness of the two training methods. But, from the interview result, participants preferred traditional training over e-learning training.

\subsection{Learning Process}

In the Faculty of Engineering and Built Environment (FKAB), Universiti Kebangsaan Malaysia (UKM), the first year engineering students are compulsory to take Engineering Mathematics (Linear Algebra) while the second year students are compulsory to take Engineering Statistics course. The methods of learning process used for both courses are the modern technology-based approach such as e-learning (WILEY PLUS) and lecturing. Figure 1 summarise the learning process for both courses.

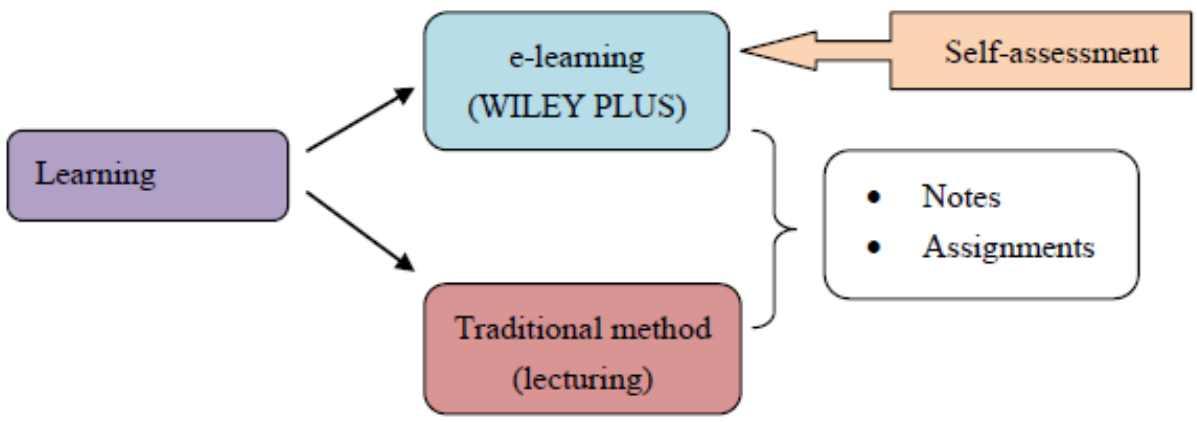

Figure 1. Learning process for Mathematics and Statistics course

In these courses, the lecture will be held in class within one to three hours each week. Usually, lecturer will use handouts, power-point slide and e-learning (WILEY PLUS) as tools for teaching. All notes and assignment are given to them in lecture class and through WILEY PLUS. Usually, lecturers will assign them to do the assignments after they have finished learning a chapter.

WILEY PLUS is a web-based application that assists lecturers in preparing for classes and lectures and automates the processes of assigning and grading homework for each student. It allows students to complete their homework online and receive instant feedback on their work. There are three main components in Wiley Plus i.e. Read, Study \& Practice, Assignments and Gradebook. Read, Study \& Practice constitute an area for self-guided student activities. It contains full online texts and may also include other study materials to help students learn about the subject. The Assignment tab is where students navigate to see all of their assignments with their given due dates. Assignments can be either in the form of scored questions or unscored tasks such as readings, animations or practice problems. Gradebook allows students to view all their scores from the assignments in their class. It also allows lecturers to view all the students' scores for each assignment. 
Although all notes and assignments are given to the students through both methods but e-learning is more to self assessment and self study where they can receive instant scores after finishing each assignment and access the notes everywhere, anytime they want. Therefore, students can evaluate themselves individually by determine which topic they cannot perform or understand for any course. Whilst, in traditional method such lecturing the assignments are done by group (consists of two to three students) which the scores for each assignment will be marked by the lecturer and the scores were not received immediately as e-learning.

In comparing between lecturing and e-learning, we are interested to test if there is any differences exist between these two methods and to identify which method is more important and agreeable or favourable to the students.

\section{Methodology}

A set of questionnaire was given to the students at the end of the semester with the aim of being able to evaluate how the students felt about the experience of doing e-learning and their perception towards the learning process. The number of students answered this survey were 182 for Mathematics course and 179 for Statistics course.

In this study, we are focusing only on the students' perception towards the importance and agreeability of WILEY PLUS and lecturing in their courses. The five-point Likert scale data were used to these questions whereby 1-strongly disagree, 2- disagree, 3- not sure, 4-agree, 5-strongly agree. There are two statements which serve to represent these questions, which are; Statement 1: The explanations for each topic in Mathematics/ Statistics course are clearly explained, Statement 2: Notes and Assignment provided assistance in understanding those topics. Students were required to answer these two statements using the scale, regarding the importance and the extent of their agreeability towards these statements.

In the analysis part, the descriptive and inferential statistics were used. A mean and standard deviation were used as descriptive statistics, and a paired t-test was used as inferential statistics. There are two hypotheses that are established as the following:

$H_{0}$ : There is no significant difference between WILEY PLUS and lecturing methods in Mathematics/Statistics.

$H_{1}$ : There is a significant difference between WILEY PLUS and lecturing methods in Mathematics/Statistics.

The results of the paired t-test like the two tailed p-value and 95\% confidence interval for the upper bound and lower bound were then discussed. If the p-value is lower than $5 \%$ level of significance, $\mathrm{H}_{0}$ will then be rejected. Same results are also confirmed if the mean difference lies between the upper and lower bounds of $95 \%$ confidence interval.

\section{Results and Analysis}

In the analysis part, two types of statistics were considered. One is the descriptive statistics and the other one is the inferential statistics.

\subsection{Descriptive Statistics}

A descriptive analysis consisting of mean and standard deviations for each statement was calculated and highlighted in Table 1 and Table 2 for Mathematics and Statistics respectively.

Table 1. Mean and standard deviations for each statement in Mathematics

\begin{tabular}{|c|c|c|c|c|c|c|c|}
\hline & Descriptive & Wiley Plus & Lecturing & & Descriptive & Wiley Plus & Lecturing \\
\hline \multicolumn{8}{|c|}{ Statement 1: The explanations for each topic in Mathematics course are clearly explained. } \\
\hline \multirow[t]{2}{*}{ Importance } & Mean & 3.63 & 4.53 & Agreeable & Mean & 3.66 & 4.49 \\
\hline & $\begin{array}{l}\text { Standard } \\
\text { deviation }\end{array}$ & 1.02 & 0.88 & & $\begin{array}{l}\text { Standard } \\
\text { deviation }\end{array}$ & 0.98 & 0.90 \\
\hline \multicolumn{8}{|c|}{ Statement 2: Notes and Assignment provide assistance in understanding those topics. } \\
\hline \multirow[t]{2}{*}{ Importance } & Mean & 3.86 & 4.56 & Agreeable & Mean & 3.85 & 4.57 \\
\hline & $\begin{array}{l}\text { Standard } \\
\text { deviation }\end{array}$ & 1.04 & 0.88 & & $\begin{array}{l}\text { Standard } \\
\text { deviation }\end{array}$ & 0.97 & 0.88 \\
\hline
\end{tabular}

As indicated in the column 'lecturing' of Table 1, the results of mean are almost 5 and the standard deviation values are less than one. On the five-point Likert scale, these values lie between "agree" and "strongly agree". Meanwhile, in the column of WILEY PLUS, the results of mean are almost 4 and standard deviation is less than the standard deviation for lecturing. The values of means for WILEY PLUS then lie between "not sure" and agree". 
Table 2. Mean and standard deviations for each statement in Statistics

\begin{tabular}{|c|c|c|c|c|c|c|c|}
\hline & Descriptive & Wiley Plus & Lecturing & & Descriptive & Wiley Plus & Lecturing \\
\hline \multicolumn{8}{|c|}{ Statement 1: The explanations for each topic in Statistics course are clearly explained. } \\
\hline \multirow[t]{2}{*}{ Importance } & Mean & 2.86 & 4.61 & Agreeable & Mean & 2.84 & 4.58 \\
\hline & $\begin{array}{l}\text { Standard } \\
\text { deviation }\end{array}$ & 1.20 & 0.74 & & $\begin{array}{l}\text { Standard } \\
\text { deviation }\end{array}$ & 1.21 & 0.78 \\
\hline \multicolumn{8}{|c|}{ Statement 2: Notes and Assignment provide assistance in understanding those topics. } \\
\hline \multirow[t]{2}{*}{ Importance } & Mean & 2.99 & 4.59 & Agreeable & Mean & 3.08 & 4.56 \\
\hline & $\begin{array}{l}\text { Standard } \\
\text { deviation }\end{array}$ & 1.25 & 0.76 & & $\begin{array}{l}\text { Standard } \\
\text { deviation }\end{array}$ & 1.20 & 0.80 \\
\hline
\end{tabular}

Table 2 shows that in the lecturing column, the results of mean are almost 5 and the standard deviation values are less than one. These values lie between "agree" and "strongly agree". By contrast, in the WILEY PLUS column, the results of mean are almost 3 and standard deviation is greater than one which indicates that students are not sure of the importance and the agreeability towards both statements.

Overall, in comparing the mean and standard deviations of students' perception towards WILEY PLUS and lecturing in Mathematics and Statistics courses, the mean values for lecturing are greater than WILEY PLUS. Therefore, it can be concluded that lecturing is more important and agreeable to the students for each topic contained in Statistics and Mathematics courses. The values of standard deviation for lecturing are less than WILEY PLUS, which also concludes the same results as the values of mean. In order to make these results valid, an inferential statistics was then conducted and the results discussed in the next section.

\subsection{Inferential Statistics}

A paired t-test for Mathematics and Statistics courses was calculated as displayed in Table 3 and Table 4 respectively.

Table 3. Results of the paired t-test for differences in the mean of WILEY PLUS and lecturing in Mathematics course

\begin{tabular}{|c|c|c|c|c|c|c|c|c|}
\hline \multirow[b]{2}{*}{ Statement } & \multirow[b]{2}{*}{ Pair } & \multirow[t]{2}{*}{$\mathbf{t}$} & \multirow[t]{2}{*}{ df } & \multirow[t]{2}{*}{$\begin{array}{c}\text { Sig } \\
\text { (2-tailed) }\end{array}$} & \multirow[t]{2}{*}{$\begin{array}{c}\text { Mean } \\
\text { Difference }\end{array}$} & \multirow[t]{2}{*}{$\begin{array}{l}\text { Std-Error } \\
\text { Difference }\end{array}$} & \multicolumn{2}{|c|}{$\begin{array}{l}95 \% \text { Confidence } \\
\text { Interval of the } \\
\text { Difference }\end{array}$} \\
\hline & & & & & & & Lower & Upper \\
\hline $\begin{array}{l}\text { Statement 1: } \\
\text { Importance }\end{array}$ & $\begin{array}{l}\text { WileyPlus- } \\
\text { Lecturing }\end{array}$ & -10.1384 & 181 & 0.00 & -0.9065 & 0.0894 & -1.0830 & -0.7301 \\
\hline Aggreeability & $\begin{array}{l}\text { WileyPlus- } \\
\text { Lecturing }\end{array}$ & -9.03075 & 181 & 0.00 & -0.8241 & 0.0912 & -1.0042 & -0.6441 \\
\hline $\begin{array}{l}\text { Statement 2: } \\
\text { Importance }\end{array}$ & $\begin{array}{l}\text { WileyPlus- } \\
\text { Lecturing }\end{array}$ & -8.24001 & 181 & 0.00 & -0.7033 & 0.0853 & -0.8717 & -0.5348 \\
\hline Aggreeability & $\begin{array}{l}\text { WileyPlus- } \\
\text { Lecturing }\end{array}$ & -8.6384 & 181 & 0.00 & -0.7197 & 0.0833 & -0.8841 & -0.5553 \\
\hline
\end{tabular}

Table 3 displays the results of the paired t-test for differences in the mean of WILEY PLUS and lecturing in Mathematics course. The results of the two-tailed p-value of 0.00 for all pairs are less than the significant level of $0.05 . \mathrm{H}_{0}$ can, therefore, be rejected and indicates that there is no significant two-tailed difference in the means of WILEY PLUS and lecturing in Mathematics course for all pairs. The same results appear where the mean difference for all pair lies between 95\% confidence interval upper and lower bounds of the difference as stated in the last column in Table 3. The negative values of the mean difference for all pairs suggest that lecturing is more important and agreeable to the students compared to WILEY PLUS for both statements. 
Table 4. Results of the paired t-test for differences in the means of WILEY PLUS and lecturing in Statistics

\begin{tabular}{|c|c|c|c|c|c|c|c|c|}
\hline \multirow[b]{2}{*}{ Statement } & \multirow[b]{2}{*}{ Pair } & \multirow[t]{2}{*}{$\mathbf{t}$} & \multirow[t]{2}{*}{ df } & \multirow[t]{2}{*}{$\begin{array}{c}\text { Sig } \\
\text { (2-tailed) }\end{array}$} & \multirow{2}{*}{$\begin{array}{c}\text { Mean } \\
\text { Differenc } \\
\text { e }\end{array}$} & \multirow{2}{*}{$\begin{array}{c}\text { Std-Error } \\
\text { Differenc } \\
\text { e }\end{array}$} & \multicolumn{2}{|c|}{$\begin{array}{l}\text { 95\% Confidence } \\
\text { Interval of the } \\
\text { Difference }\end{array}$} \\
\hline & & & & & & & Lower & Upper \\
\hline $\begin{array}{l}\text { Statement 1: } \\
\text { Importance }\end{array}$ & $\begin{array}{l}\text { WileyPlus } \\
\text {-Lecturing }\end{array}$ & -16.5679 & 178 & 0.00 & -1.75419 & 0.105879 & $\begin{array}{c}-1.9631 \\
3\end{array}$ & $\begin{array}{c}-1.545 \\
25\end{array}$ \\
\hline Aggreeability & $\begin{array}{l}\text { WileyPlus } \\
\text {-Lecturing }\end{array}$ & -15.8127 & 178 & 0.00 & -1.73743 & 0.109876 & $\begin{array}{c}-1.9542 \\
6\end{array}$ & $\begin{array}{c}-1.520 \\
6\end{array}$ \\
\hline $\begin{array}{l}\text { Statement 2: } \\
\text { Importance }\end{array}$ & $\begin{array}{l}\text { WileyPlus } \\
\text {-Lecturing }\end{array}$ & -14.6878 & 178 & 0.00 & -1.59777 & 0.108782 & $\begin{array}{c}-1.8124 \\
3\end{array}$ & $\begin{array}{c}-1.383 \\
1\end{array}$ \\
\hline Aggreeability & $\begin{array}{l}\text { WileyPlus } \\
\text {-Lecturing }\end{array}$ & -13.5798 & 178 & 0.00 & -1.48045 & 0.109019 & $\begin{array}{c}-1.6955 \\
8\end{array}$ & $\begin{array}{c}-1.265 \\
31\end{array}$ \\
\hline
\end{tabular}

Table 4 displays the results of the paired t-test for differences in the means of WILEY PLUS and lecturing in Statistics. The results of the two-tailed p-value of 0.00 for all pairs are less than the significant level of $0.05 . \mathrm{H}_{0}$ can, therefore, be rejected and indicates that there is no significant two-tailed difference in the means of WILEY PLUS and lecturing in Statistics course for all pairs. The same results appear where the mean difference for all pairs lies between $95 \%$ confidence interval upper and lower bounds of the difference as stated in the last column in Table 4. The negative values of the mean difference for all pairs indicate that lecturing is more important and agreeable to the students compared to WILEY PLUS, for both statements.

\section{Conclusion}

The results of descriptive and inferential statistics indicate that there is a significant difference between e-learning (WILEY PLUS) and traditional method (lecturing) in Mathematics and Statistics courses. Thus, it can be concluded that in both courses, lecturing is more important and agreeable by the students for the delivery of each topic in Statistics and Mathematics courses in a way that the explanation about each topic was clearly provided, and all notes and assignment provided by lecturer had assisted them in understanding those topics. It is recommended that for further analysis, other factors should also be investigated to find out the weaknesses of the e-learning. Noorhelyna (2010) suggests that, WILEY PLUS should be improved in order to attract students in using this application- improvement of which, may include adding tool for mathematical equations and symbols, and including other information from other sources.

\section{Acknowledgements}

The authors would like to thank Universiti Kebangsaan Malaysia for sponsoring this research under the grant UKM-PTS-2011-022 UKM-PTS-2012-016, PTS-2012-091 and OUP-2012-126. This work supported by the Centre for Engineering Education Research, Faculty of Engineering and Built Environment, Universiti Kebangsaan Malaysia, Bangi, Selangor, Malaysia.

\section{References}

Anonymous.

(2009).

What is $a$

lecture?

Retrieved

from http://www.askus.ecu.edu.au/app/answers/detail/a_id/684/ /what-is-a-lecture\%3F

Berge, Z. L., \& Collins, M. (Eds.). (1995). Computer-Mediated Communication and the Online Classroom.Cresskill. NJ: Hampton Press.

Browne, L., Mehra, S., Rattan, R., \& Thomas, G. (2004) . Comparing lecture and e-learning as pedagogies for new experienced professionals in dentistry. British Dental Journal, 197(2), 95-97. http://dx.doi.org/10.1038/sj.bdj.4811484

Chang Liaw, S. S., Huang, H. M., \& Chen, G. D. (2007). Surveying instructor and learner attitudes toward e-learning. Computers and Education, 49(4), 1066-1080. http://dx.doi.org/10.1016/j.compedu.2006.01.001

Foster, B., Perfect, C., \& Youd, A. (2004). A completely client-side approach to e-assessment and e-learning of Mathematics and Statistics. from http://ilin.asee.org/Conference2006program/Papers/Morsi-P11.pdf

Ghani, S. A. (2009). Cooperative Learning versus The Lecture Method of Instruction in An Introductory 
Statistics Course. Jurnal Sains dan Matematik, 1(1), 59-71.

Ibrahim, A., Rozar, N. B. M., Razik, M. A. B., \& Kormin, K. B. (2011). Comparing Effectiveness E-Learning Training and Traditional Training in Industrial Safety and Health. Annual Conference on Innovations in Business \& Management London, UK, 2011. Retrieved from http://www.cibmp.org/Papers/Paper619.pdf

Joan, M., \& Alan, K. (1996). The 'Change-up' in Lectures, TRC Newsletter, 8(1), 5-6.

Johnson, H. D., Dasgupta, N., Zhang, H., \& Evans, M. A. (2009). Internet Approach versus Lecture and Lab-Based Approach for Teaching an Introductory Statistical Methods Course: Students' Opinions. Teaching Statistics, 31(1), 21-26. http://dx.doi.org/10.1111/j.1467-9639.2009.00335.x

Liaw, S. S., Huang, H. M., \& Chen, G. D. (2007). Surveying instructor and learner attitudes toward e-learning. Computers and Education, 49(4), 1066-1080. http://dx.doi.org/10.1016/j.compedu.2006.01.001

Noorhelyna, R., Norngainy, M. T., Nuryazmin, A. Z., Azami, Z., Hafizah B., \& Albashah, N. L. S. (2010). E-Learning in Vector Calculus. Kongres Pengajaran dan Pembelajaran UKM 2010.

Norngainy, M. T., Azami, Z., Fadiah Hirza, M. A., Nur Arzilah, I., \& Mohd Hanif, O. (2010), Implementing e-learning in mathematics engineering for better understanding. AIKED'10 Proceedings of the 9th WSEAS international conference on Artificial intelligence, knowledge engineering and data bases: 250-253.

Richard. (2004). E-learning compared with face to face: Differences in the academic achievement of postgraduate business students. Australasian Journal of Educational Technology, 20(3), 316-336. Retrieved from http://www.ascilite.org.au/ajet/ajet20/ladyshewsky.html

Sahin, Y., \& Yorek, N. (2009). A comparison of problem-based learning and traditional lecture students' expectations and course grades in an introductory physics classroom. Scientific Research and Essay, 4(8), 753-762.

White, G. (2003). The Changing Landscape: e-Learning in Schools. Retrieved from http://www.education.edu.au/papers/changing_landscape_gw 